industrial, and financial communities. Two or three biotechnology companies have already been created as a result of Bioregio in Lower Saxony alone" he said. New companies created by the Bioregio in Lower Saxony include TheraGen, a stem cell transplantation enterprise involving the Hannover Medical School, the Fraunhofer Society, and the Society for Biotechnological Research in Braunschweig and two commercial companies, medcon GmbH (Walsrode) and Pharma Biotechnologie (Hannover).

Detlev Ganten, Director of the Max Delbrück Center in Berlin, believes that BMBF got its timing just right. "Not so long ago, German scientists considered funds from industry to be dirty money. Now they are much more willing to cooperate with the commercial sector and the Bioregio competition has accelerated this process." Several new enterprises, including Transgenics in Berlin Buch and the gene therapy company, Hepavec (Berlin), have already been launched as collaborations between the academic and industrial sectors in Berlin.

In Bavaria and Nord Rhein Westfalen (NRW), both of which already had substantial biotechnology initiatives, the Bioregio competition has created even greater impetus. In addition to new biotechnology enterprises such as Cardiogene (Dusseldorf) and Labiogene (Cologne) in NRW, and Medigen and Mor- phosys (both Munich) in Bavaria, both regions now have large venture capital funds headed by pharmaceutical companies: Bayer (Leverkusen) in NRW and Boehringer Mannheim (Mannheim) in Bavaria.

Thus the BMBF, with a relatively small investment of DM1.7 million (\$1.1 million) to support the proposals and even before awarding the prizes - which represent less than ten percent of its DM1000 million (\$667 million) medical and biotechnology budget-has apparently stimulated a huge increase in biotechnology investment.

The prestige of the competition has helped get things moving. "The size of the prize is not the most important aspect," says Patricia Solaro, managing director of Biogen $\mathrm{Tec}$ (Cologne), a group that heads the Nord Rhein Westfalen consortium. "We already have a well-developed biotechnology initiative in NRW and have raised DM70 million ( $\$ 46.7$ million) by ourselves. For us, prestige is one of the more important aspects. The prestige will enable us to attract the additional foreign investment that we need to remain competitive in world markets." A recent report prepared for BMBF (see "Tax cuts and global strategy," below) argues that the ability to raise private capital domestically and to attract inward investment will be essential if Germany is to attain a world standard in biotechnology.
Many of the competitors believe that politics may play a significant role in the final decision, although $\mathrm{BMBF}$ has denied this vehemently, pointing to the international nature of the jury. The political color of the regional state government may be particularly important. "Consortia from regions such as Nord Rhein Westfalen, with Socialist-Green majorities, have had to fight extra hard," says Solaro. "We fear that the CDU/FDP coalition [the Christian Democrat/Free Democrat government] will not want to reward its political foes in the state governments with the prestige of a Bioregio." Conversely, the close contacts between Bavaria's ruling right-wing Christian Social Union and the national CDU-dominated government may provide the Munich proposal with an extra boost. Then, of course, there is "the Eastern factor." The federal government has already invested heavily in the redevelopment of science in the former-communist East and, although by criteria of scientific quality they might be unlikely to qualify, it is widely thought that at least one of the Bioregios will be created in the East, with Jena being the favorite location.

Rüttgers" vision is to "make Germany number one for biotechnology in Europe." This is ambitious, but the Bioregio competition has already proved to be a cost-effective shot in the arm for German biotechnology.

\title{
Tax cuts and global strategy to fuel German biotechnology
}

The economic and employment value of biotechnology to Germany could be significantly lower than previous predictions have suggested, even under favorable conditions. Thus concludes a report published in October by the ministry of education, science, research and technology (BMBF; Bonn). The report, commissioned from Prognos, the European Centre for Economic Research and Strategy Consulting (Basel, $\mathrm{CH}$ ), says that the application of biotechnology in Germany could be worth DM4.1 billion ( $\$ 2.7$ million) by 2000 [compared with around DM2.0 million ( $\$ 1.3$ million) now] and support 100,000 jobs.

Prognos surveyed 30 multinational corporations currently applying biotechnology and 50 small- and medium-sized biotechnology companies in Germany. It also assessed economic contributions from suppliers and service industries, such as consultants, law firms and finance institutions based on the expected increase in demand from core biotechnology companies. Of the 100,000 jobs, between 23,000 and 40,000 would be

Michael R. Schuppenhauer is at Prognos AG, Missionsstrasse 62, CH-4012 Basel, Switzerland

(schuppenhauer@tech.chem.ethz.ch). in the core commercial sector, 20,000 in statefunded or academic research as now, while 40,000 to 50,000 jobs will be in secondary supply and service sectors.

Much of the predicted growth to DM4.1 billion ( $\$ 2.7$ billion) by the year 2000 is the result of $25 \%$ growth per year in therapeutics and $9 \%$ per year in diagnostics. The large year-onyear growth $(17 \%)$ in agricultural biotechnology only takes the estimated turnover in this area to under DM50 million ( $\$ 33.4$ million), reflecting a very low starting point. Companies in agricultural and food biotechnology, uncertain of public reactions to novel foods, thought biotechnology's contribution in these areas in German would be negligible.

Even to deliver DM4.1 million ( $\$ 2.7$ million) worth of products and 100,000 jobs, several billions of DM would need to be invested per year for several years, the report suggests. Only then could a small-company-based biotechnology scene comparable with that in the US emerge. To mobilize the necessary private and institutional capital, Prognos suggested that the German government should look at tax incentives for high-risk ventures; one proposal was that investment gains reinvested into growth-oriented companies should be taxed at lower rates. Furthermore, the report concludes, intellectual property and management awareness and skills would need to be developed within small companies and by academic entrepreneurs.

The report also suggests that the persistent quantitative drain of industrial research and development activities from Germany to the US can only be remedied in the longterm through a substantial strategic operation to relocate leading researchers and companies back to Germany while providing similar incentives to foreign companies for inward investment.

Prognos' figures are more cautious than those compiled by the Senior Advisory Group Biotechnology (now part of the pan European lobby organization, EuropaBIO; Brussels) and by accountants, Ernst \& Young (London) partly because of the uncertainties in environmental, agricultural, and food biotechnology and the R\&D drain to the United States.

Prognos also cites the increasing globalization in biotechnology and the concomitant concentration of biotechnology companies outside Germany (particularly in California and the US East Coast) as factors that erode growth within the German borders. Europespecific factors such as relative high raw materials costs and the stagnation or contraction of European health-care markets also have an influence.

Michael R. Schuppenhaue 